\title{
Deleterious effect of TRIS buffer on growth rates and pigment content of Gracilaria birdiae Plastino \& E.C. Oliveira (Gracilariales, Rhodophyta)
}

\author{
Suzana Ursi ${ }^{1}$, Melina Guimarães² and Estela Maria Plastino ${ }^{1,3}$
}

Received: Juy 5, 2007. Accepted: November 29, 2007

\begin{abstract}
RESUMO - (Efeito deletério do tampão TRIS nas taxas de crescimento e no conteúdo pigmentar de Gracilaria birdiae Plastino \& E.C. Oliveira (Gracilariales, Rhodophyta)). O presente trabalho avaliou os efeitos do tampão Tris (hydroxymethyl)-aminomethane (TRIS) e a interação com a concentração de nutrientes no desenvolvimento em Gracilaria birdiae, espécie presente no litoral brasileiro utilizada comercialmente na produção de ágar. As respostas às diferentes condições de cultivo foram avaliadas por meio das taxas de crescimento e conteúdo pigmentar (clorofila $a$, ficoeritrina, ficocianina e aloficocianina). A solução de nutrientes de Provasoli com e sem adição de TRIS foi testada nas concentrações de 12,5, 25 e 50\%. O pH foi também monitorado. G. birdiae cresceu melhor em ausência de TRIS e em baixas concentrações de nutrientes, 12,5 e $25 \%$ (taxas de crescimento de 10,8-11,3\%.dia ${ }^{-1}$ ). As maiores concentrações de ficoeritrina e clorofila $a$ foram observadas na ausência de TRIS em 12,5 e 25\% (Ficoeritrina, 649,6-698.0 $\mu \mathrm{g} \mathrm{g}^{-1}$ de biomassa fresca; Clorofila $a$, 156,0-168,6 $\mu \mathrm{g} \mathrm{g}^{-1}$ de biomassa fresca), evidenciando o efeito deletério do TRIS no crescimento e nos conteúdos de clorofila $a$ e ficoeritrina. Os dados demonstram ainda a importância da utilização de concentrações de nutrientes adequadas em cultivos em laboratório, dependendo das características intrínsecas de cada espécie.
\end{abstract}

Palavras-chave: meio de cultura, TRIS (hydroximetil)-aminometano, Gracilaria birdiae, crescimento, pigmentos

\begin{abstract}
Deleterious effect of TRIS buffer on growth rates and pigment content of Gracilaria birdiae Plastino \& E.C. Oliveira (Gracilariales, Rhodophyta)). This work evaluated the effects of Tris (hydroxymethyl)-aminomethane (TRIS) buffer and its interaction with nutrient concentration on the development of Gracilaria birdie, a common species on the Brazilian coast that has been exploited for agar production. Responses to different conditions were assessed through growth rates and pigment content (chlorophyll $a$, phycoerythrin, phycocyanin and allophycocyanin). Provasoli's nutrient solution with and without TRIS addition was tested at concentrations of $12.5,25$ and $50 \%$. The $\mathrm{pH}$ was also monitored. G. birdiae grew better in the absence of TRIS and at low nutrient concentrations, 12.5 and $25 \%$ (growth rates of 10.8-11.3\% .day ${ }^{-1}$ ). Higher contents of phycoerythrin and chlorophyll $a$ were observed without TRIS at 12.5 and 25\% (Phycoerythrin, 649.6-698.0 $\mu \mathrm{g} \mathrm{g}^{-1}$ fresh biomass; Chlorophyll $a, 156.0-168.6 \mu \mathrm{g} \mathrm{g}{ }^{-1}$ fresh biomass). These findings highlight the deleterious effect of TRIS on growth and phycoerythrin and chlorophyll $a$ content. They also demonstrate the importance of appropriate nutrient concentration for laboratory cultures, depending on the intrinsic characteristics of each species.
\end{abstract}

Key words: culture medium, TRIS (hydroxymethyl)-aminomethane, Gracilaria birdiae, growth, pigments

\section{Introduction}

In vitro cultures have significantly contributed to phycology development in the last decades. Life histories of many species of seaweeds have been accessed through these techniques, as well as physiological and genetic processes. In vitro cultures have also been important tools for selection and domestication of species (van der Meer 1982). Environmental factors, such as light, nutrients, salinity and temperature, can be manipulated in the laboratory, which allows researchers to evaluate their effects on vegetative and reproductive development of different species or strains (Oliveira et al. 1995; Plastino 2003). Although in vitro cultures have been commonly utilized, some basic points still need further investigation, such as the adequacy of culture media for a selected species.

Many seaweed culture media still have a number of potentially undesirable characteristics, when their chemical composition is examined. Firstly, concentrations of some ions, notably phosphate and some micronutrients are substantially greater in the media than in natural seawater (Woelkerling et al. 1983). This is the case in seawater enriched with Provasoli's solution (PES - McLachlan 1973) and with von Stosch's solution (VS - Edwards 1970), commonly applied in rhodophytes in vitro cultivation. Secondly, concentrations of some other ions, especially calcium, sulphate and borate, while generally similar to those in seawater, appear to be totally unnecessary for ensuring stability of the medium

\footnotetext{
1 Universidade de São Paulo, Instituto de Biociências, C. Postal 11.461, 05422-970 São Paulo, SP, Brasil

2 Universidade Católica de Brasília, Brasília, DF, Brasil

3 Corresponding Author: emplasti@usp.br
} 
(Woelkerling et al. 1983). Thirdly, some media employ organic buffers which are metabolizable, such as glycylglycine (McLachlan 1973) and Tris (hydroxymethyl)-aminomethane, TRIS (Hanisak 1979), which seem to have negative effects on life material. Of these, TRIS is the most controversial, because its effectiveness of stabilized $\mathrm{pH}$ has not been clearly demonstrated (Woelkerling et al. 1983). In addition, the deleterious effect of TRIS has been observed for some phytoplankton species (Harrison et al. 1980) and freshwater algae (Smith \& Foy 1974). Studies on seaweeds and seagrasses have proposed that TRIS has a deleterious effect on photosynthesis by inhibition of mechanisms such as the transport of $\mathrm{HCO}_{3}{ }^{-}$across the plasma membrane (Axelsson et al. 2000; Hellblom et al. 2001) or $\mathrm{O}_{2}$ evolution in Photosystem II (Sofrová et al. 1978; Rickert et al. 1991; Jegerschold \& Styring 1996). This buffer also stimulates bacterial growth, leading to a negative effect on cultures (Fábregas et al. 1993).

Although most reports indicate a negative effect of TRIS, some authors have raised some of its beneficial effects, by enhancing the availability of carbon, vitamins and hormones when promoting the increase of bacteria in the growth media (Ogata 1966; Provasoli \& Pintner 1980; Woelkerling et al. 1983). The question is if the beneficial effects of TRIS would compensate the damage caused by its addition, especially in the photosynthetic apparatus.

TRIS is a component of the PES medium, which is probably the most utilized for laboratory seaweed culture (Oliveira et al. 1995). Similarly to the majority of culture media, it was originally developed for cold area species from nutrient-rich waters. However, it has been widely used, in spite of the geographic origin of the alga. If it were taken into account, it would be expected that species from oligotrophic tropical waters do not need such high nutrient concentrations for their laboratory cultures. Nevertheless, PES has been commonly utilized for species from the tropical Brazilian coast (e.g. Berchez \& Oliveira 1990; Yokoya \& Oliveira 1992).

This work was planned to analyze the effects of TRIS buffer and its interaction with nutrient concentration on growth and pigment content of a tropical species. The target organism was Gracilaria birdiae, one of the main species exploited for agar production in Brazil (Plastino \& Oliveira 2002), which has been the subject of color strain investigations in our laboratory (e.g. Ursi et al. 2003; Plastino et al. 2004). G. birdiae occurs from the northeast to the southeast coast of Brazil (Plastino \& Oliveira 2002), which is predominantly characterized by oligotrophic warm waters (Boltovskoy et al. 1999).

\section{Material and methods}

Apical segments of three infertile tetrasporophytes of Gracilaria birdiae Plastino \& E.C. Oliveira obtained in the laboratory were utilized in the experiments. These tetrasporophytes were originated from cystocarpic specimens derived from a tetrasporophyte collected in a natural population from Anchieta Beach $\left(20^{\circ} 80^{\prime} \mathrm{S}\right.$ and $40^{\circ} 65^{\prime} \mathrm{W}$ ), Espírito Santo state (Brazil) (Plastino et al. 2004). Unialgal cultures were established as described by Plastino \& Oliveira (1990).

Standard culture conditions were $25 \pm 1{ }^{\circ} \mathrm{C}, 95 \pm$ $10 \mu \mathrm{mol}$ photon $\mathrm{m}^{-2} \mathrm{~s}^{-1}$ (Osram $40 \mathrm{~W}$ daylight fluorescent tubes), 14-10 light-dark cycle, with 30 min aeration every hour, and sterile seawater ( $32 \mathrm{psu}, 7.90 \mathrm{pH}$ ) enriched with culture medium renewed weekly.

Three different concentrations of PES (McLachlan 1973) were employed: $12.5,25$, and $50 \%$. These concentrations were also tested utilizing PES without TRIS addition (PES-TRIS). Three replicates each with three apical segments from three different individuals were cultivated separately in flasks with $900 \mathrm{ml}$ of enriched seawater.

Growth rates were evaluated by weekly weighing for 28 days. Fresh biomass was utilized to calculate the growth rates (Lignell \& Pedersén 1989). Initial biomass of each replicate was $10 \mathrm{mg}$.

The $\mathrm{pH}$ values were measured after PES dilution in seawater using a pH meter (Denver mod. 10234). After one week of cultivation, the apical segments were removed from the flasks and the $\mathrm{pH}$ of the medium was measured again.

Pigments were quantified by spectrophotometry using an HP 8452A spectrophotometer. Pigment extractions were carried out at the end of the growth experiment at $4{ }^{\circ} \mathrm{C}$, according to Kursar et al. (1983) with modifications (Plastino \& Guimarães, 2001). Briefly, the samples were disrupted by grinding with liquid nitrogen and $50 \mathrm{mmol} / \mathrm{L}$ phosphate buffer, $\mathrm{pH}$ 5.5. Crude extracts were centrifuged at $36,000 \mathrm{~g}$ for $25 \mathrm{~min}$ to get the phycobiliproteins. Chlorophyll $a$ was extracted after dissolving the pellet in $90 \%$ acetone, and centrifuging at $12,000 \mathrm{~g}$ for $15 \mathrm{~min}$. Pigment concentrations were calculated according to Kursar et al. (1983) for phycobiliproteins (allophycocyanin, phycocyanin and phycoerythrin), and Jeffrey and Humphrey (1975) for chlorophyll $a$.

Growth rates and pigment concentrations were analyzed by two-factor ANOVA (independent variables: PES concentrations and presence or absence of TRIS). Newman-Keuls post hoc tests were applied when necessary. 


\section{Results}

Growth rates - The growth rates of Gracilaria birdiae were affected by both PES concentration and presence or absence of TRIS (interaction between factors $\mathrm{F}=4.352$, $\mathrm{P}<0.05)$. Branches showed higher growth rates when cultivated in PES without TRIS and low nutrient concentration, 12.5 and 25\% (Fig. 1, Tab. 1). Similar growth rates were observed in PES, regardless of concentration (Fig. 1, Tab. 1), whereas in the absence of TRIS, G. birdiae grew better in 12.5 and $25 \%$ than in $50 \%$.

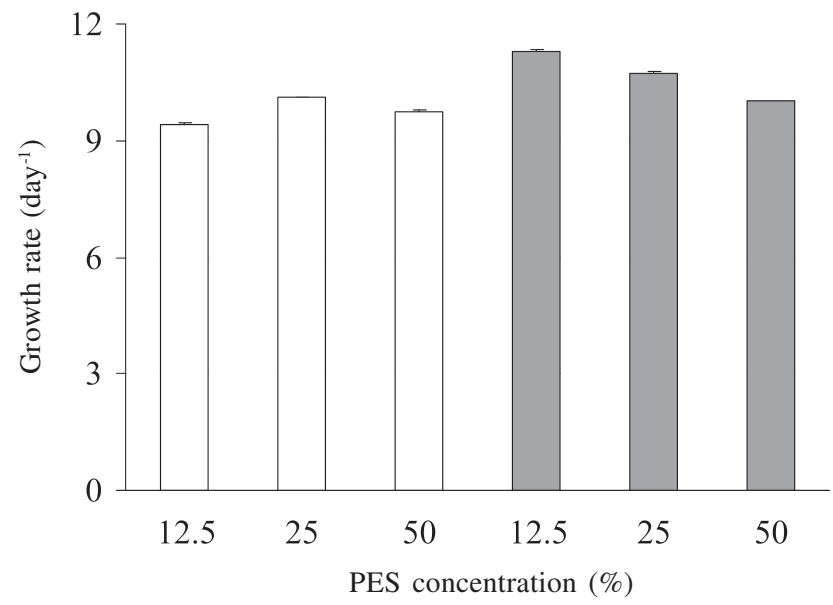

Figure 1. Growth rates of Gracilaria birdiae Plastino \& E.C. Oliveira after 28 days of cultivation in seawater enriched with different concentrations (50, 25, and 12.5\%) of PES with (PES) and without TRIS (PES-TRIS). Mean $(n=3) \pm$ Standard deviation. $(\square=$ PES; = PES-TRIS).

Table 1. Newman-Keuls post hoc test of the two-factor ANOVA of growth rates of Gracilaria birdiae Plastino \& E.C. Oliveira after 28 days of cultivation in seawater enriched with different concentrations (50, 25, and $12.5 \%$ ) of PES with (PES) and without TRIS (PES-TRIS). Independent variables: PES concentration and presence or absence of TRIS.*, significant differences $(\mathrm{P}<0.05)$.

\begin{tabular}{lccccc}
\hline & PES & PES & PES & \multicolumn{2}{c}{ PES-TRIS PES-TRIS } \\
& $50 \%$ & $25 \%$ & $12.5 \%$ & $50 \%$ & $25 \%$ \\
\hline PES 25\% & 0.632 & & & & \\
PES 12.5\% & 0.423 & 0.337 & & & \\
PES-TRIS 50\% & 0.544 & 0.764 & 0.346 & & \\
PES-TRIS 25\% & 0.087 & 0.112 & $0.031 *$ & 0.150 & \\
PES-TRIS 12.5\% & $0.017 *$ & $0.034 *$ & $0.006 *$ & $0.034 *$ & 0.261 \\
\hline
\end{tabular}

$\mathrm{pH}$ measurement - The buffer effect of TRIS was evident when culture medium was added to seawater. The initial $\mathrm{pH}$ values in seawater enriched with PES were similar to the original seawater $\mathrm{pH}$ (7.9), while the initial values in seawater enriched with PES-TRIS were slightly higher (Tab. 2). Despite the differences in initial $\mathrm{pH}$, the values observed after one week of cultivation were similar between seawater enriched with PES and PES-TRIS, showing that the buffer effect of TRIS was not maintained through cultivation (Tab. 2). During one week, $\mathrm{pH}$ values of seawater with PES-TRIS varied less than the $\mathrm{pH}$ values of seawater enriched with PES. The $\mathrm{pH}$ variation was sensitive to $\mathrm{PES}$ concentration as well as to the presence or absence of TRIS (interaction between factor $\mathrm{F}=18.881, \mathrm{P}>0.05$ ). No difference in $\mathrm{pH}$ variation was observed among the nutrient solution concentrations when branches were cultivated in PESTRIS. However, this difference was verified in PES, in

Table 2. $\mathrm{pH}$ variation (Initial $\mathrm{pH}$ - Final $\mathrm{pH}$ ) of seawater utilized in Gracilaria birdiae Plastino \& E.C. Oliveira cultivation for one week. Seawater was enriched with different concentrations (50, 25, and $12.5 \%)$ of PES with (PES) and without TRIS (PES-TRIS). Mean $(\mathrm{n}=3) \pm$ Standard deviation.

\begin{tabular}{lccl}
\hline & Initial $\mathrm{pH}$ & Final pH & Ph variation \\
\hline PES 50\% & $7.89 \pm 0.00$ & $8.05 \pm 0.01$ & $0.16 \pm 0.01$ \\
PES 25\% & $7.96 \pm 0.00$ & $8.08 \pm 0.01$ & $0.12 \pm 0.01$ \\
PES 12.5\% & $8.02 \pm 0.00$ & $8.09 \pm 0.01$ & $0.07 \pm 0.01$ \\
PES-TRIS 50\% & $8.12 \pm 0.00$ & $8.11 \pm 0.01$ & $0.01 \pm 0.01$ \\
PES-TRIS 25\% & $8.14 \pm 0.00$ & $8.12 \pm 0.02$ & $0.02 \pm 0.02$ \\
PES-TRIS 12.5\% & $8.13 \pm 0.00$ & $8.10 \pm 0.00$ & $0.03 \pm 0.00$ \\
\hline
\end{tabular}

which variation increased with rising concentrations of nutrient solution (Tab. 2).

Pigment content - Concentrations of allophycocyanin and phycocyanin did not vary in any PES concentration tested (allophycocyanin, $\mathrm{F}=1.475, \mathrm{P}>0.05$; phycocyanin $\mathrm{F}=3.896, \mathrm{P}>0.05)$, nor in the presence or absence of TRIS (allophycocyanin, $\mathrm{F}=2.142$, $\mathrm{P}>0.05$; phycocyanin, $\mathrm{F}=2.301, \mathrm{P}>0.05$ ) (Fig. 2).

Both chlorophyll $a$ and phycoerythrin concentrations were affected by PES concentration and presence or absence of TRIS, as demonstrated by the significant interaction between these factors (chlorophyll $a, \mathrm{~F}=5.540, \mathrm{P}<0.05$; phycoerythrin $\mathrm{F}=6.973$, $\mathrm{P}<0.05)$. The highest concentrations of chlorophyll $a$ were observed in branches cultivated in seawater enriched with 12.5 and $25 \%$ of PES-TRIS (Fig. 2). The chlorophyll $a$ content of branches cultivated in all concentrations of complete PES was similar to those of branches cultivated in PES-TRIS at 25\% and 50\%. Higher concentrations of phycoerythrin were observed among branches cultivated in seawater enriched with 12.5 and $25 \%$ of PES-TRIS, and in branches cultivated in complete PES at $50 \%$ (Fig. 2). Although pigment content varied according to culture condition, there was no color variation among branches. 

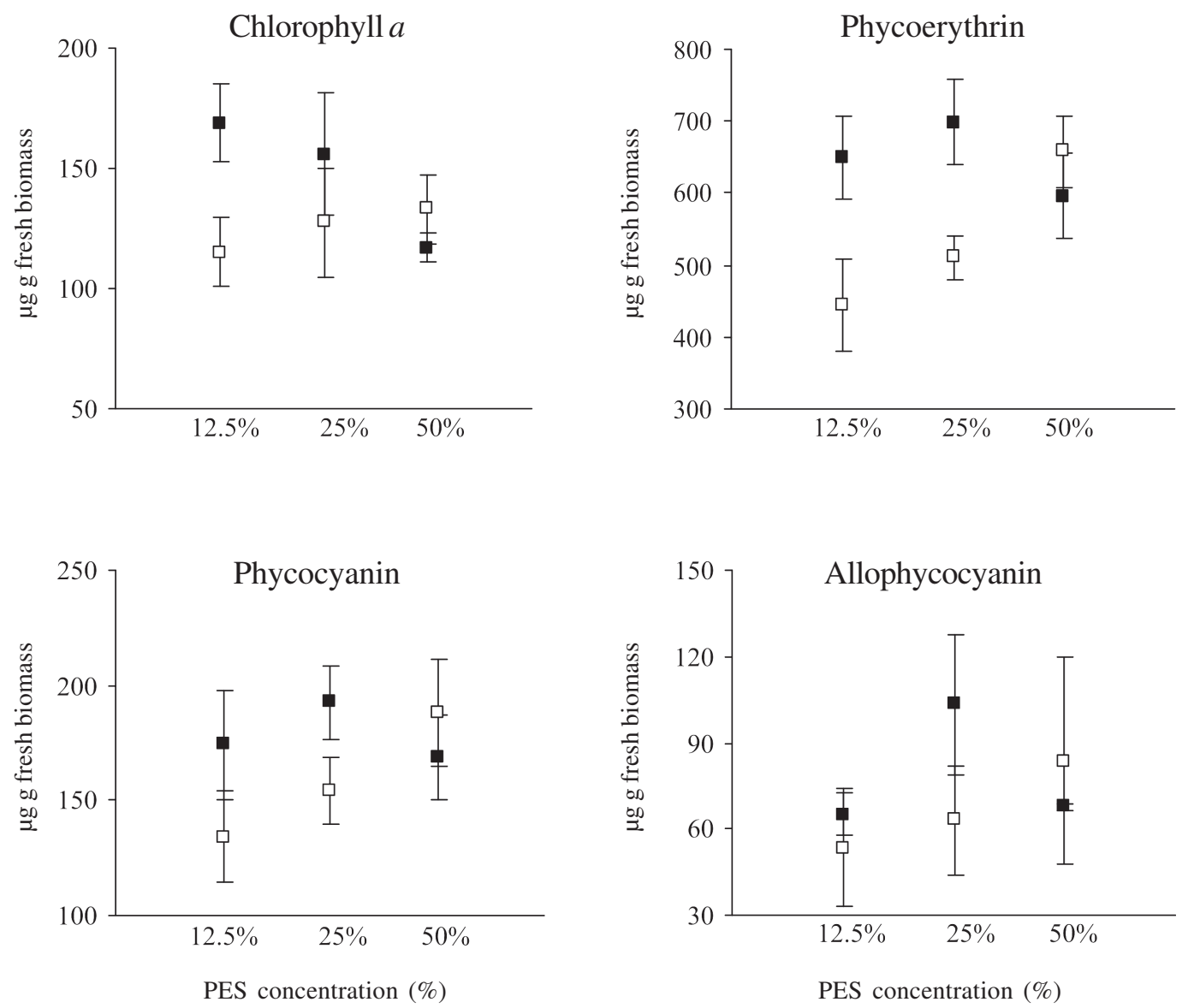

Figure 2. Chlorophyll $a$, phycoerythrin, phycocyanin and allophycocyanin concentrations of Gracilaria birdiae Plastino \& E.C. Oliveira cultivated in seawater enriched with different concentrations (50, 25, and 12.5\%) of PES with (PES) and without TRIS (PES-TRIS). Means $(\mathrm{n}=3) \pm$ Standard deviation.

\section{Discussion}

The higher growth rates of Gracilaria birdiae observed in PES without TRIS when compared to PES with TRIS corroborates the idea that the eventual benefits of this buffer in minimizing $\mathrm{pH}$ fluctuation may be smaller than its deleterious effects. However, it is clear that a consensus about TRIS effects does not exist because they vary among different organisms. From seven species of seaweeds cultivated in artificial marine culture medium (MCM - Woelkerling et al. 1983) with and without TRIS addition, five grew better in medium without the buffer, one showed worse growth in this condition and the other one was not sensitive to TRIS. The negative effect of this buffer was also reported for Kappaphycus alvarezii, which has shown lower growth rates in PES than in PES-TRIS (Paula et al. 2001), as observed for G. birdiae. The growth of some phytoplancton species was also lowered in cultures containing TRIS (Harrison et al. 1980).

Color variation among branches of G. birdiae cultivated in different conditions has not been observed. By contrast, Kappaphycus alvarezii (Paula et al. 2001) and G. domingensis (personal observation) showed changes in color when cultivated in media with TRIS. Although quantitative analysis of pigment was not performed on these species, it is reasonable to suppose that TRIS interfered in their pigment content, as observed here for G. birdiae.

Pigment analysis of $G$. birdiae showed that neither allophycocyanin nor phycocyanin was affected by TRIS or PES concentration, in contrast with phycoerythrin and chlorophyll $a$. The inner position of allophycocyanin and phycocyanin in the phycobilisome structure (Talarico 1996) may protect them from TRIS action, while phycoerythrin and chlorophyll $a$ are probably more assessable to this buffer.

The type of interaction between TRIS and pigments is unknown. Our assumption is that this buffer may be negatively acting on nitrogen acquisition/assimilation, since phycoerythrin and chlorophyll $a$ are highly nitrogenated molecules. Previous studies showed that low nitrogen availability diminishes the contents of phycoerythrin and chlorophyll $a$ (Lapointe 1981; Lapointe et al. 1984). 
A positive correlation was observed between chlorophyll $a$ concentration and growth rates of G. birdiae, which is probably explained by an increase in the photosynthetic efficiency as the concentration of this pigment increased. In contrast with chlorophyll $a$, the content of phycoerythrin did not seem to be strongly related to the growth of G. birdiae. These results are expected since chlorophyll a plays a fundamental function in photosynthesis, while phycoerythrin is not essential for light-harvesting proposes if the light level is sufficient for algal metabolism. The metabolic pathway that involves phycoerythrin synthesis is complex. Apart from a lightharvesting function in photosynthesis, this pigment has a function in nitrogen storage (Lapointe 1981). This secondary function can explain the high concentration of phycoerythrin in 50\% of PES, despite TRIS presence. The high nitrogen content in the medium might have compensated the negative effect of TRIS, maintaining the stability of phycoerythrin concentration.

Besides the deleterious effects of TRIS on growth and phycoerythrin and chlorophyll $a$ content of G. birdiae, our results suggested that TRIS is not essential for buffering purposes. Its buffer effect was evident when culture medium was added to seawater. However, final $\mathrm{pH}$ values were similar between seawater enriched with PES and PES-TRIS, which showed that this effect was not maintained during the cultivation period. Studies on Callithamnion byssoides (Woelkerling et al. 1983) and on a variety of phytoplankton species (Harrison et al. 1980) also concluded that TRIS was not efficient in stabilizing $\mathrm{pH}$ during cultivation.

An increase of seawater $\mathrm{pH}$ during one week of cultivation was observed when PES was utilized, but it was not verified in PES-TRIS. These results suggest that $\mathrm{pH}$ increase might be attributed to bacterial growth and not to ordinary algal metabolism. The stimulatory effect of TRIS on bacterial growth has already been verified in microalgal cultures (Fábregas et al. 1993).

Our results suggested that G. birdiae might be adapted to a low nutrient content, since the higher growth rates were verified in higher PES dilutions. It demonstrates the need for adequate nutrient concentration, depending on intrinsic characteristics of each species. Dilutions of the original culture media can be more appropriate for laboratory culture of several species, especially those from oligotrophic warm waters. Therefore, it is not recommended the use of TRIS in future cultures of G. birdiae. Furthermore, this buffer can potentially impair the development of other species, being necessary further studies to evaluate how general this negative effect can be.

\section{Acknowledgments}

This work was supported by Fundação de Amparo à Pesquisa do Estado de São Paulo (FAPESP - 98/11943-1 and 00/10394-6) and Conselho Nacional de Desenvolvimento Científico e Tecnológico (CNPq 300148/93-3 and 132846/98-5). The authors acknowledge Eurico C. de Oliveira and Nair S. Yokoya for manuscript review.

\section{References}

Axelsson, L.; Mercado, J.M. \& Figueroa, F.L. 2000. Utilization of $\mathrm{HCO}_{3}{ }^{-}$at high $\mathrm{pH}$ by the brown macroalga Laminaria saccharina. European Journal of Phycology 35: 53-59.

Berchez, F.A.S. \& Oliveira, E.C. 1990. Growth rate, in vitro, of the agar producing seaweed Pterocladia capillacea (Rhodophyta, Gelidiaceae) under different conditions of light, temperature and nutrients. Revista Brasileira de Botânica 13: $55-59$.

Boltovskoy, D.; Gibbons, M.J.; Hutchings, L. \& Binet, D. 1999. General biological features of South Atlantic. Pp. 1-42. In: D. Boltovskoy (ed.). South Atlantic Zooplankton. Leiden, Backhuys Publishers.

Edwards, P. 1970. Illustrated guide of seaweeds and sea grasses in vicinity of Porto Arkansas, Texas. Contributions in Marine Science 15: 1-228.

Fábregas, J.; Vásquez, V.; Buenaventura, C. \& Otero, A. 1993. Tris not only controls the $\mathrm{pH}$ in microalgal cultures, but also feeds bacteria. Journal of Applied Phycology 5: 543-545.

Hanisak, M.D. 1979. Growth patterns of Codium fragile spp. tomentosoides in response to temperature, irradiance, salinity, and nitrogen source. Marine Biology 50: 319-332.

Harrison, P.J.; Waters, R.E.\& Taylor, E.J.R., 1980. A broad spectrum artificial seawater medium for coalstal and open ocean phytoplankton. Journal of Phycology 16: 28-35.

Hellblom, F.; Beer, S.; Björk, M. \& Axelsson, L. 2001. A buffer sensitive inorganic carbon utilization system in Zostera marina. Aquatic Botany 69: 55-62.

Jeffrey, S.W. \& Humphrey, G.F. 1975. New spectrophotometric equation for determining chlorophylls $a, b, c_{1}$ and $c_{2}$ in higher plants, algae and natural phytoplankton. Biochemical Physiology Pflanz 167: 191-194.

Jegerschold, C. \& Styring, S. 1996. Spectroscopic characterization of intermediate steps involved in donor-side-induced photoinhibition of photosystem II. Biochemistry 35: 7794-7801.

Kursar, T.A.; van der Meer, J.P. \& Alberte, R.S. 1983. Lightharvesting system of the red alga Gracilaria tikvahiae. I. Biochemical analyses of pigment mutations. Plant Physiology 73: $353-360$.

Lapointe, B.E. 1981. The effects of light and nitrogen on growth, pigment content, and biochemical composition of Gracilaria foliifera v. angustissima (Gigartinales, Rhodophyta). Journal of Phycology 17: 90-95.

Lapointe, B.E.; Dawes, C.J. \& Tenore, K.R. 1984. Interactions between light and temperature on the physiological ecology of Gracilaria tikvahiae (Gigartinales: Rhodophyta). II. Nitrate uptake and levels of pigments and chemical constituents. Marine Biology 80: 171-178.

Lignell, A. \& Pedersén, M. 1989. Agar composition as a function of morphology and growth rate. Studies on some morphological strains of Gracilaria secundata and Gracilaria verrucosa (Rhodophyta). Botanica Marina 32: 219-227. 
McLachlan, J. 1973. Growth media-marine. Pp. 25-51. In: J.R. Stein (ed.). Handbook of phycological methods. Cultures methods and growth measurements. Cambridge, Cambridge University Press.

Ogata, E. 1966. Photosynthesis in Porphyra tenera and some other marine algae as affected by Tris (hydroxymethyl)-aminomethane in artificial media. Botanical Magazine 79: 271-282.

Oliveira, E.C.; Paula, E.J.; Petti, R. \& Plastino, E.M. 1995. Metodologias para cultivo no axenico de macroalgas marinas in vitro. Pp. 429-447. In: K.V. Alveal, M.E. Ferrario, E.C. Oliveira \& E. Sar (eds.). Manual de métodos Ficológicos. Concepción, Universidad de Concepción.

Paula, E.J.; Erbert, C. \& Pereira, R.T.L. 2001. Growth rate of the carrageenophyte Kappaphycus alvarezii (Rhodophyta, Gigartinales) in vitro. Phycological Research 49: $155-161$

Plastino, E. M. 2003. Cultivo em laboratorio y selección de cepas em algas rojas (Rhodophyta). Memorias Curso Internacional Algas 2003: 53-58.

Plastino, E.M. \& Guimarães, M. 2001. Diversidad intraespecífica. Pp. 19-27. In: K.V. Alveal \& T.J. Antezana (eds.). Sustentabilidad de la Biodiversidad. Concepción, Universidad de Concepción.

Plastino, E.M. \& Oliveira, E.C. 1990. Crossing experiments as an aid to the taxonomic recognition of the agarophyte alga Gracilaria (Rhodophyta, Gigartinales). Pp. 127-133. In: E.C. Oliveira \& N. Kautsky (eds.). Cultivation of Seaweeds in Latin American. São Paulo, Universidade de São Paulo.

Plastino, E.M. \& Oliveira, E.C. 2002. Gracilaria birdiae (Gracilariales, Rhodophyta), a new species from the tropical South Atlantic with terete frond and deep spermatangial conceptacles. Phycologia 41: 389-396.
Plastino, E.M.; Ursi, S. \& Fujii, M.T. 2004 Color inheritance, pigment characterization, and growth of a rare light green strain of Gracilaria birdiae (Gracilariales, Rhodophyta). Phycological Research 52:45-52.

Provasoli, L. \& Pintner, I.J. 1980. Bacteria induced polymorphism in an axenic laboratory strain of Ulva lactuca (Chlorophyceae). Journal of Phycology 16: 196-201.

Rickert, K.W.; Sears, J.; Beck, W.F. \& Brudvig, G.W. 1991. Mechanism of irreversible inhibition of $\mathrm{O}_{2}$ evolution in photosystem-II by TRIS (hydroxymethyl)-aminomethane. Biochemistry 30: 7888-7894.

Smith, R.V. \& Foy, R.H. 1974. Improved hydrogen ion buffering of media for culture of freshwater algae. British Phycological Journal 9: 239-245.

Sofrová, D.; Wilhelm, J.; Naus, J. \& Leblová, S. 1978. Effects of TRIS and analogous hydroxycompounds on photosystem II of blue-green algae. Photosynthetica 12: 391-398.

Talarico, L. 1996. Phycobiliproteins and phycobilisomes in red algae: adaptive responses to light. Scientia Marina 60: 205-222.

Ursi, S.; Pedersén, M.; Plastino, E.M. \& Snoejis, P. 2003. Intraspecific variation of photosynthesis, respiration and photoprotective carotenoides in Gracilaria birdiae (Gracilariales, Rhodophyta). Marine Biology 142: 997-1007.

Van der Meer, J.P. 1982. The domestication of seaweeds. Bioscience 33:172-176.

Woelkerling, W.J.; Spencer, K.G. \& West, J.A. 1983. Studies on selected corallinaceae (Rhodophyta) and other algae in a defined marine culture medium. Journal of Experimental Marine Biology and Ecology 67: 61-77.

Yokoya, N.S. \& Oliveira, E.C. 1992. Temperature responses of economically important red algae and their potential for maricultura in Brazilian waters. Journal of Applied Phycology 4: $339-345$. 